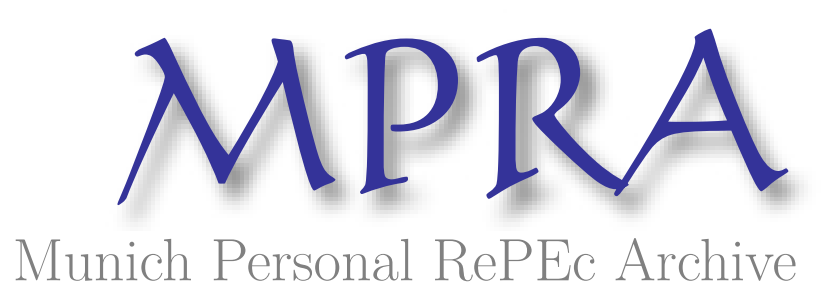

\title{
Africa's Economic Growth: A Fallacy of Numbers?
}

\author{
Acheampong, Theophilus \\ University of Aberdeen
}

May 2013

Online at https://mpra.ub.uni-muenchen.de/70500/

MPRA Paper No. 70500, posted 10 Jun 2016 14:51 UTC 


\section{AFRICA'S ECONOMIC GROWTH: A FALLACY OF NUMBERS? By Theo Acheampong. ${ }^{1}$}

\section{Table of Contents}

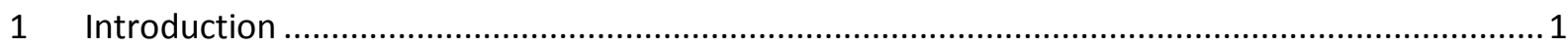

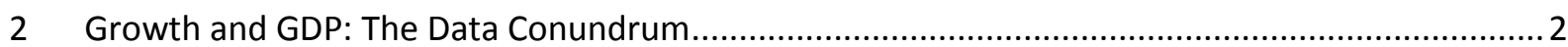

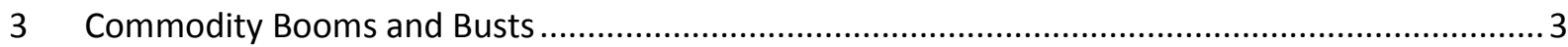

4 The Critical Role of Agriculture, Services and the Manufacturing Sectors ................................... 5



6 Structural Adjustments and Public Sector Reforms.............................................................

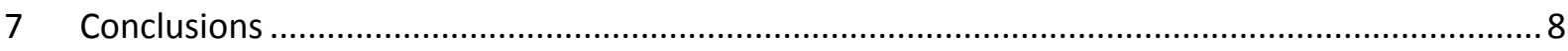

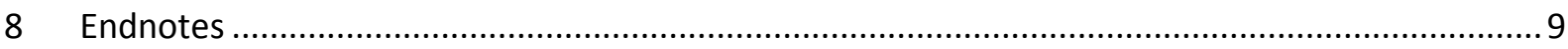

\section{Figures}

Figure 1: African GDP Growth Estimates (Source: The Economist, 2011) ......................................... 1

Figure 2: Fast growing Sub-Saharan African economies in 2012 (Source: Africa Pulse, 2012) .............. 2 Figure 3: The aggregate short-run effects of the current commodity boom on GDP per capita growth in Africa's commodity exporting countries (Source: Collier, 2007)

Figure 4: Sub-Saharan Africa: growth rate (right scale) and commodity prices (annual price index, 2005=100, real 2005 dollars, left scale), 1960-2011 (Source: Sindzingre, 2013).

Figure 5: Government revenue from natural resources in 2011 (\% General government revenue)

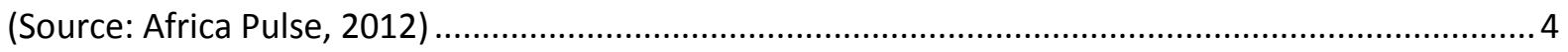

Figure 6: FDI Inflows into Africa (Source: Source: Africa Pulse, 2012)............................................... 5

Figure 7: Value Added Manufacturing (Source: Ernst \& Young, 2013).............................................. 6

Figure 8: 2002 Population Pyramids of SSA and the World (Source: US Census Bureau) ...................... 7

Figure 9: Africa's GDP Growth Episodes (Source: Devarajan \& Fengler, 2012) .................................... 8

Figure 10: Economic Transformation Model (Source: Source: Ernst \& Young, 2013) .......................... 9

\footnotetext{
${ }^{1}$ The author is a PhD student in Economics at the University of Aberdeen. He can be reached at theo acheampong@yahoo.com
} 


\section{AFRICA'S ECONOMIC GROWTH: A FALLACY OF NUMBERS?}

\section{Introduction}

Only a decade ago, Africa's socioeconomic growth potential was confined to the doldrums and back alley of underdevelopment. Today, the international media continues to be abuzz with common memes such as 'Africa Rising' and 'The Final Investment Frontier' amongst others. Many writers often cite poverty, disease, starvation, wars and tribal conflict fuelled by a vicious neo-colonial legacy as the cause of the continent's woes. Much as these may be true, we have witnessed Africa rise like the proverbial phoenix over the last decade to join the league of global and regional economic blocs negotiating for a fairer and better world economic system. For example, two contenders out of the nine candidates vying to become the next World Trade Organisation (WTO) chairman are from Africa, namely Ghana and Kenya. The economic growth witnessed in Africa over the last decade has led The Economist ${ }^{1}$, which captured Africa in 2000 as the hopeless continent to make a dramatic turnaround of its forecast. In their December 2011 edition, the magazine dedicated a cover edition. ${ }^{2}$ with the title "The hopeful continent: Africa rising". Many other publications such as Time and Foreign Policy Magazines have followed suit with similar Africa rising theme espousing the potential of the continent to become the next Asian economic miracle.

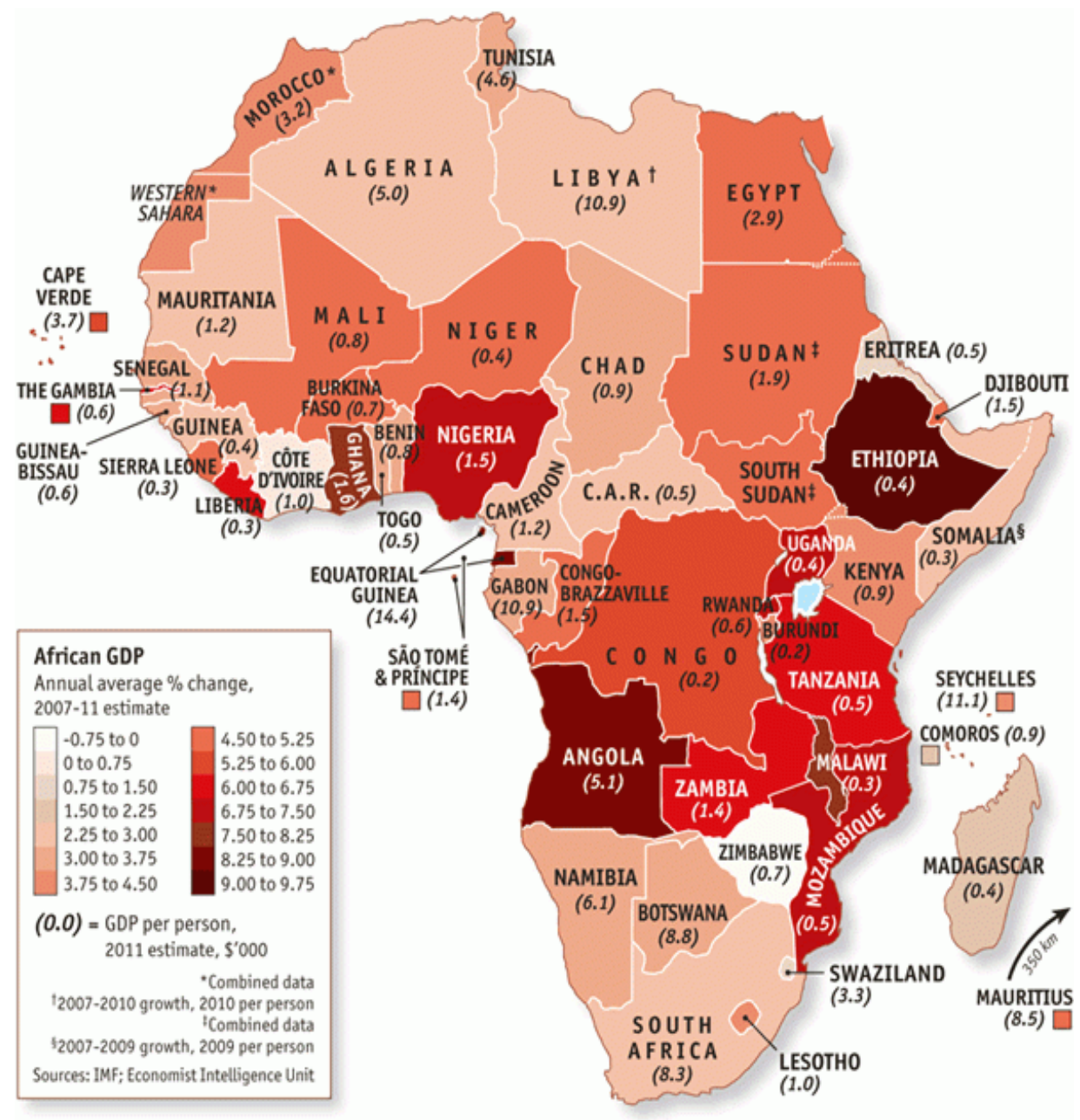

Figure 1: African GDP Growth Estimates (Source: The Economist, 2011) 


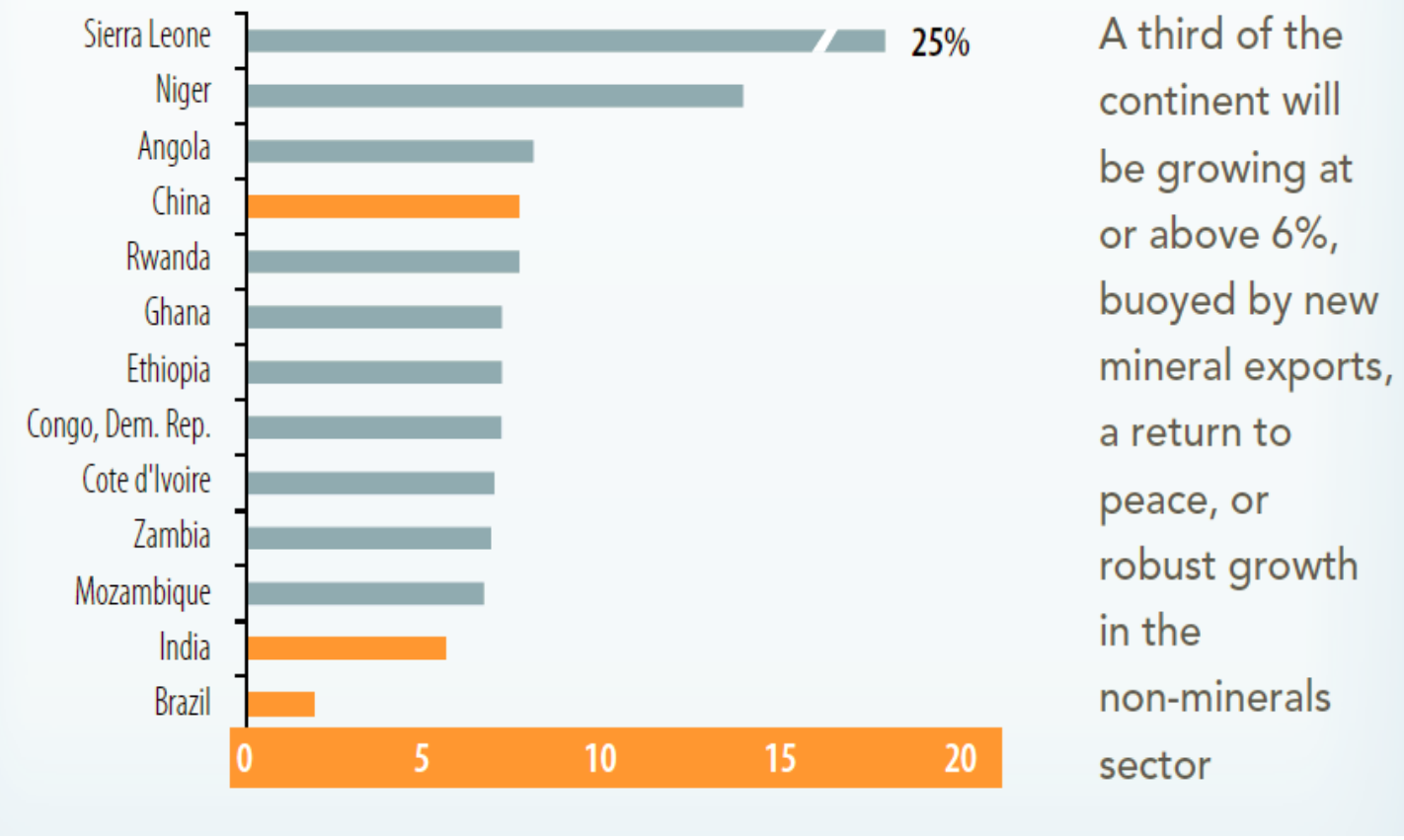

Figure 2: Fast growing Sub-Saharan African economies in 2012 (Source: Africa Pulse, 2012)

\section{Growth and GDP: The Data Conundrum}

On the back of this new media hype over Africa's potential; one cannot help but wonder whether the recent high growth rates and increased Foreign Direct Investment (FDI) inflows into Africa actually correlate with real development at the grassroots level. Have these transcended into the provision of better road infrastructure, ports, railways, schools and the provision of ICT facilities?

Rick Rowden and Morten Jerven ${ }^{3}$ make the point that many of the analysis of Africa's development progress and statistics seem to forget the challenges and accuracy issues associated with the measurement of national development and economic indicators. Professor Jerven in his Foreign Policy magazine notes for example that "in November 2010, the statistics office of the government in Ghana announced that it was revising. ${ }^{4}$ its GDP estimates upwards by over 60 percent, suggesting that previous estimates had left out economic activities worth about $\$ 13$ billion. After the revision, a range of new activities were accounted for. ${ }^{5}$, and as a result Ghana suddenly, was upgraded from a low-income country to a (lower) middle-income country." He further drums. ${ }^{6}$ home the point about inaccurate growth statistics especially on the African continent where data collection remains a challenge. Using a selection of 17 Sub-Saharan African (SSA) countries, only 10 had a reference base year from which subsequent adjustments to GDP were made, thus, concluding that "more than half of the rankings of African economies up to 2009 may be pure guesswork." Many of the SSA growth statistics being churned out conceal wider issues about structural deficiencies and imbalances. These highlight a growing disconnect between the recorded macro level growth numbers and their linkage to grassroots microeconomic development.

The issue of the quality of the development and growth statistics is a serious problem that needs to be addressed by all stakeholders. These huge discrepancies in the data only points to a bigger issue about sampling methodologies that need to be critically looked at, and whether the purported growth is indeed reflective of the real development of the people. In June 2011, the IMF faulted Ethiopia's? reported growth estimate of 11.4 percent for 2010 saying that a 7.5 percent growth was more realistic. In addition, price controls, a key component of late President Meles Zenawi central 
economic planning ideology had left a clobbered private sector in need of much investments in technology to expand output.

\section{Commodity Booms and Busts}

Has Africa's purported growth been real and will the fortunes of the continent continue to be hedged on its natural resource endowments such as gold and oil that go through the cyclical dictate of the booms and busts of the global economy? Real non-oil GDP growth in some countries has been averaging 5 percent per annum over the last 4 years according to some estimates. The questions we ought to ask policy makers are; (1) how has the growth catalysed core productive sectors of the economy in agriculture, manufacturing and associated value chain linkages, and (2) how has the income inequality gap been closed over the last decade? A cursory look at the data points to the fact that many African economies are still reliant on commodity exports and are thus exposed to the huge shocks and imbalances commodity price swings tend to have on national economies. The Dutch disease. $^{8}$ elaborates the point about the consequences that arise from large increases in a country's money supply following a natural resource discovery. The increase in FDI and income brings about currency appreciation ultimately leading to inflation and a decrease in the competiveness of local industries and manufacturing. Quoting from the World Bank's 2012 World Development Indicators, Alice Sindzingre. ${ }^{9}$ notes that "in SSA in 2010, fuels represented 32 percent of total merchandise exports; manufactures, 31 percent; ores and metals, 18 percent; food, 15 percent; and agricultural raw materials, 4 percent". The graphs below highlight the fate of many African economies to commodity price shocks.

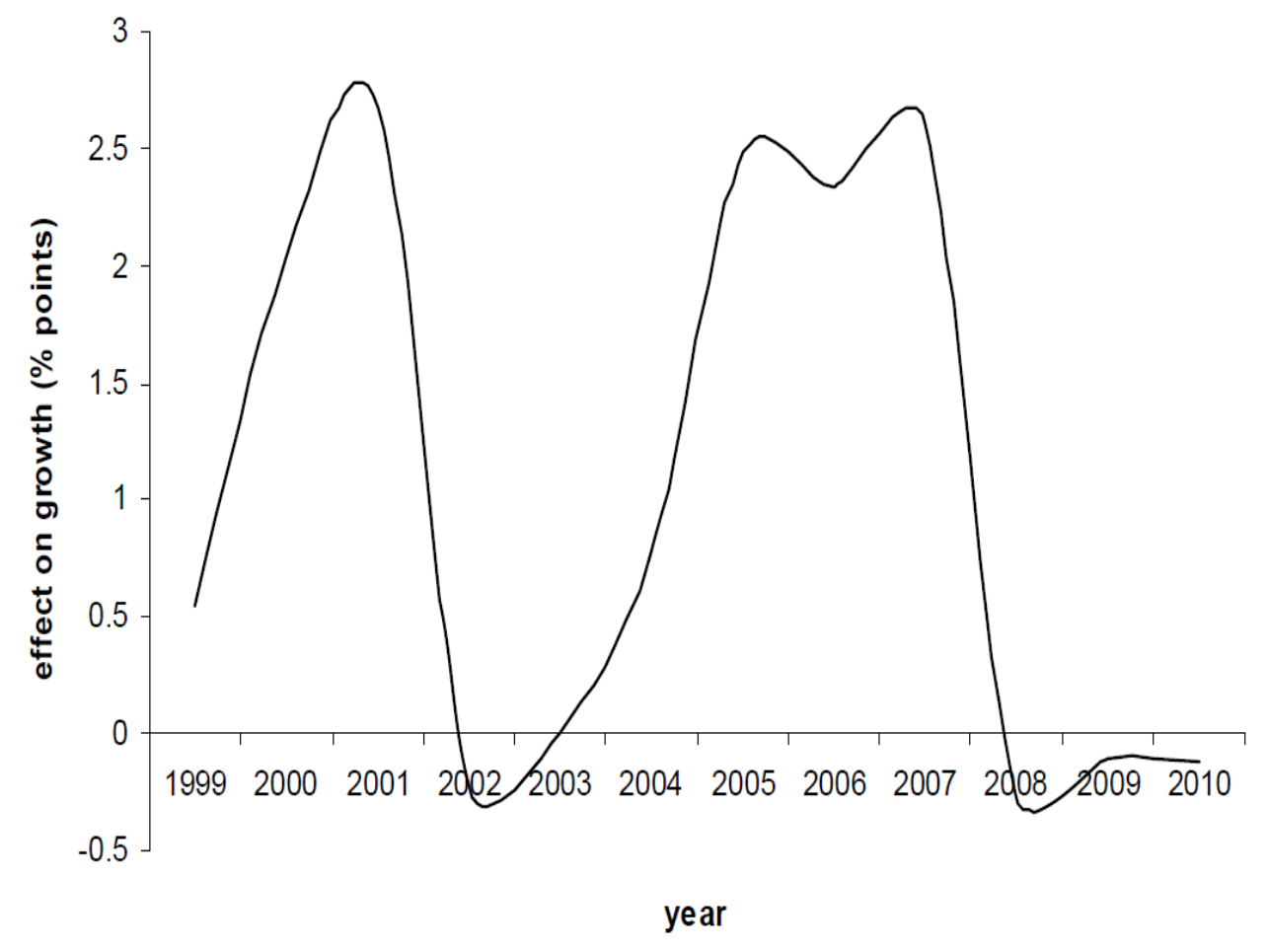

Figure 3: The aggregate short-run effects of the current commodity boom on GDP per capita growth in Africa's commodity exporting countries (Source: Collier ${ }^{10}, 2007$ ) 




Figure 4: Sub-Saharan Africa: growth rate (right scale) and commodity prices (annual price index, 2005=100, real 2005 dollars, left scale), 1960-2011 (Source: Sindzingre, 2013)



Figure 5: Government revenue from natural resources in 2011 (\% General government revenue) (Source: Africa Pulse, $2012 .{ }^{11}$ ) 


\section{The Critical Role of Agriculture, Services and the Manufacturing Sectors}

The services and construction sectors namely financials, telecoms, residential property development amongst others have shown improvements year-on-year. However, the real game changer to addressing the jobless growth, which has as its hallmark rising unemployment particularly amongst the youth will be our collective capability to leverage on emerging and proven technologies to ramp up the industrialization value chain. There is an impressive pool of youthful talent and creativity that abounds from Accra to Zanzibar, Cairo to Lusaka and Lagos to Johannesburg. Agriculture and value added manufacturing for local consumption as well as exports to regional markets should form the basis of the real economic transformation and development of the continent. The era of state farms and industries are confined to the realms of history. Instead, what governments rather ought to address as a matter of urgency is implement reforms that shift and focusses resources on removing impediments that prevents entrepreneurs from accessing land for large-scale agriculture, manufacturing and other capital inputs to production. These impediments, ultimately increase the cost of doing business and are transferred to the end consumer; thus, making the end-user products uncompetitive locally and internationally.

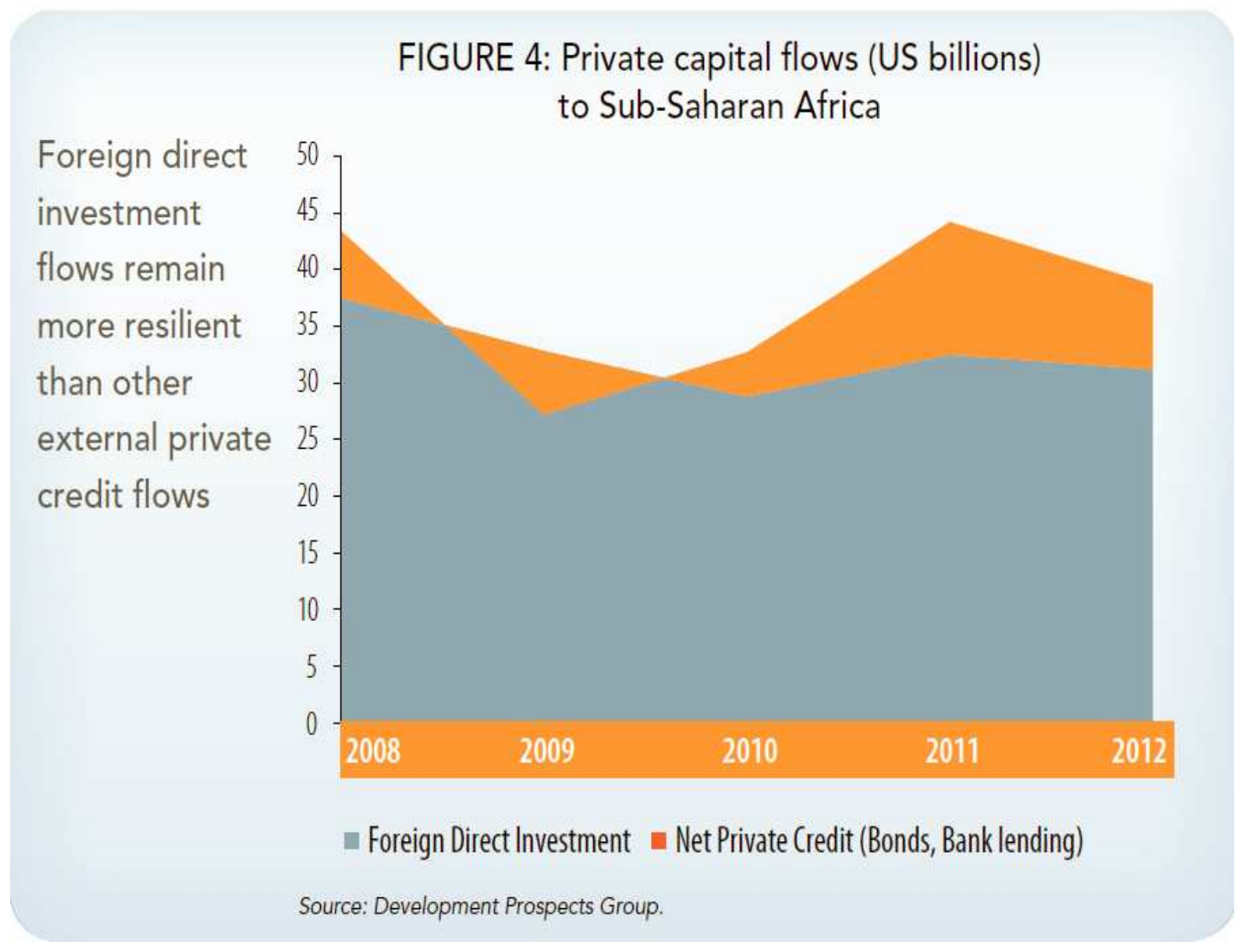

Figure 6: FDI Inflows into Africa (Source: Source: Africa Pulse, 2012) 


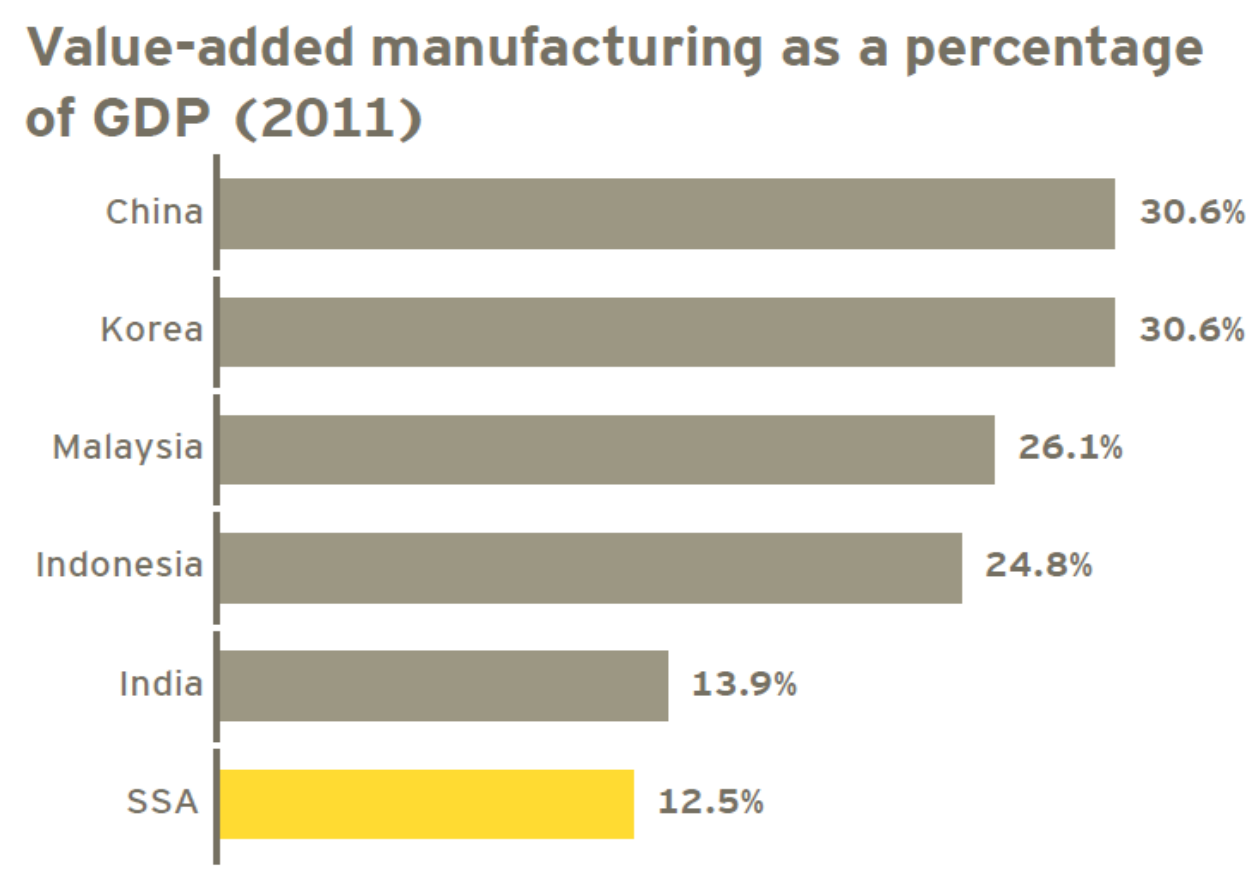

Source: World Development Indicators 2012.

Figure 7: Value Added Manufacturing (Source: Ernst \& Young. ${ }^{12}, 2013$ )

\section{The Demographic Dividend}

According to the African Economic Outlook ${ }^{13}$, young people aged between 15 and 25 represent more than 60 percent of the continent's total population and account for 45 percent of the total labour force. Unlike other developing regions, sub-Saharan Africa's population is becoming more youthful. The youth as a proportion of the total population is projected to be over 75 percent by 2015 due to high fertility rates driving the demographic momentum. It is expected that this increase in the number of young people will not decline for 20 years or more. The irony is that more than $60 \%$ of the continent's unemployed are aged 15 to 24 - and more than half of these, many women, have given up on finding work. Therefore, the current growth being experienced has been termed by many as "jobless growth." The African Development Bank's Chief Economist Mthuli Ncube has remarked it is an unacceptable reality on a continent with such an impressive pool of youth, talent and creativity. The population pyramid of SSA shown below shows the youthfulness of the population base. 


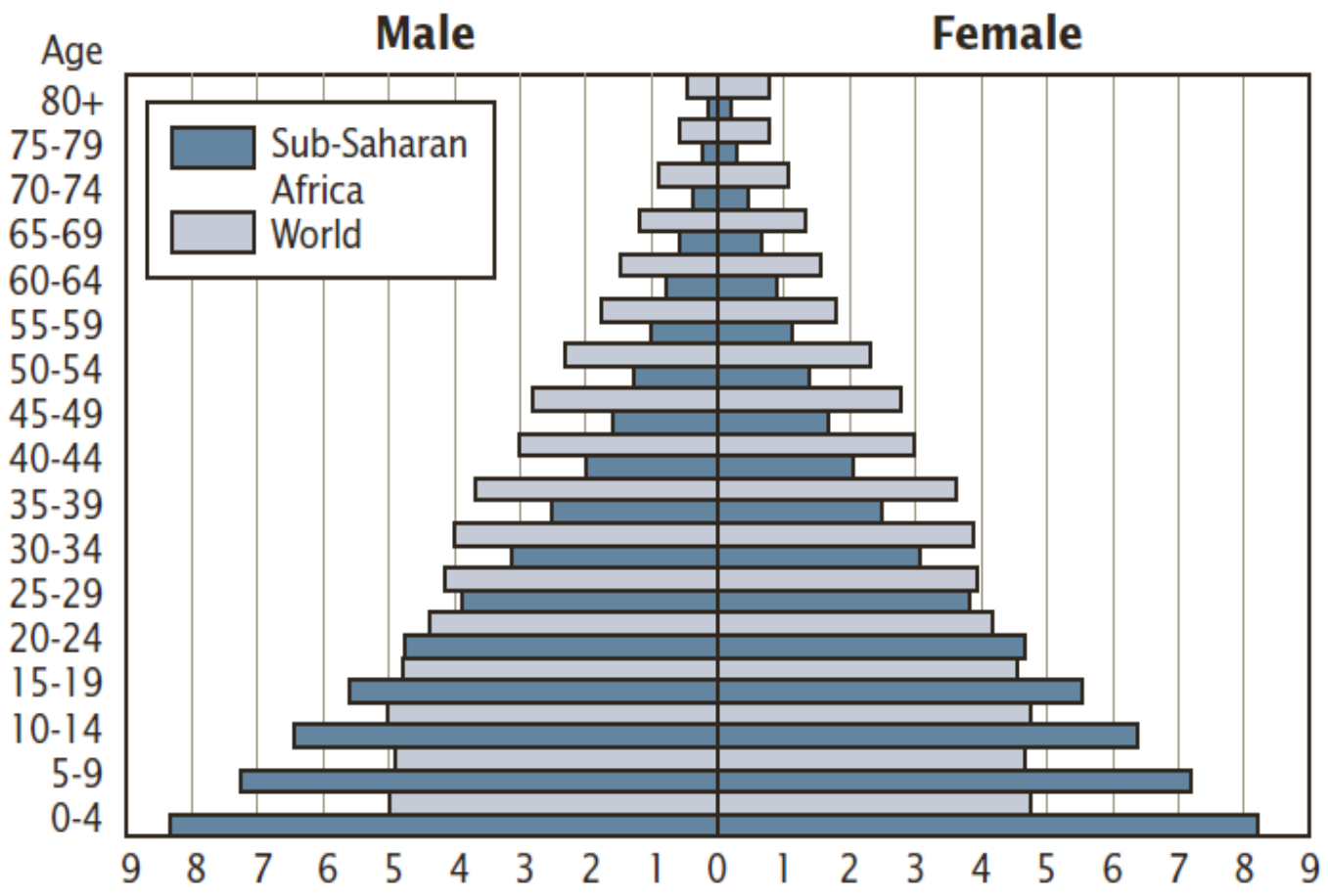

Figure 8: 2002 Population Pyramids of SSA and the World (Source: US Census Bureau ${ }^{14}$ )

\section{Structural Adjustments and Public Sector Reforms}

Despite many years of World Bank and IMF imposed Structural Adjustment Programmes (SAPs) that had a broader objective of reforming civil service, many African state institutions are over-bloated with systemic bureaucratic inefficiencies. These systemic challenges have resulted in a civil service whose marginal productivity of labour gives diminishing returns to any factor input. For example, why haven't the Ministries, Departments and Agencies (MDAs) in a lot of the respective countries become more efficient despite the enormous resources that have been poured into 20 years of public sector reforms? The Scandinavian countries are doing much better economically than their Southern European counterparts because the governments in these countries realize they need to rein in on excessive expenditure, expand the tax base, reduce the size of government to the barest minimum, and create incentives for young graduates to start their own enterprises. Incurring liabilities by borrowing on the bond market should be for growing and expanding industrial asset base of the country and needn't be for recurrent expenditure such as salaries which is the norm in some SSA countries.

An integral duty of governments in SSA ought to be in assisting and nurturing new enterprises without relying on old political patronage. These new Technical Maverick Movements. ${ }^{15}$ (TMMs) as Bright Simons of IMANI Ghana calls them can be supported with tax breaks in a manner that allows them acquire technological capital and "new technical values". This is pivotal to the success of the TTMs to transcend regional borders to become the new African Conglomerates. The adoption of technology as critical pillar of government policy could play a fundamental role in breaking the bureaucratic bottleneck that almost killed innovation on the continent. Networked traffic management, centralized procurement management, and an integrated national identification and ICT backbone systems will all help reduce the systemic inefficiencies and spur a new wave of innovation. Africa has got to catch up with the 30 year development gap lost to decades of military rule. There is a glimmer of hope as the adoption of the right technologies and a culture of excellence 
that places premium on technical value acquisition in all spheres of national life will jettison us towards the attainment of full socioeconomic freedom.

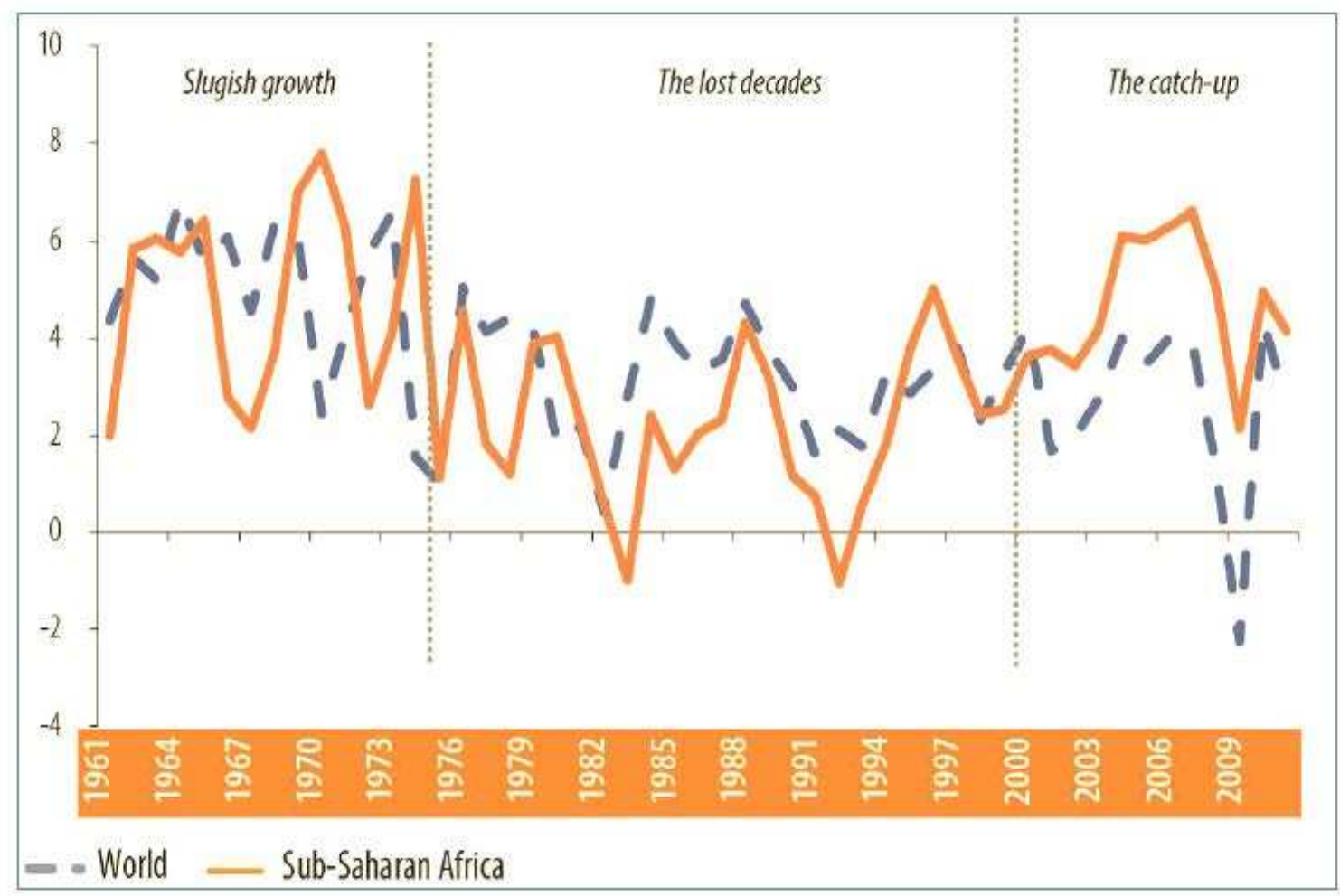

Figure 9: Africa's GDP Growth Episodes. ${ }^{16}$ (Source: Devarajan \& Fengler, 2012)

\section{Conclusions}

Africa's statistical growth may be problem may be a measurement issue and correction of GDP data to reflect the upward trend in economic activity. Nevertheless, one cannot deny the fact that Africa is growing whatever the numbers may seem to project. The real challenge will be the extent to which we can leverage and translate the macro-level growth at the micro-level to address the massive unemployment faced by the youth. That is when we can thump our chests to say real development has been achieved. Until the day we have proper address systems, well lit streets, paved roads, constant electricity, clean water supply, and a lean and efficient government, we cannot say we have arrived on the development stage. This development won't come on a silver platter. Rather, a set of well-designed and cogent policies that redefines the role of government as a key economic agent remains fundamental to our collective ability to move out of the poverty conundrum. Placing more emphasis on human capital acquisition and adaption of technologies to propel agriculture, manufacturing, and commerce within a robust macro-economic framework that focusses not only on inflation targeting but also on growth. 


\section{Economic transformation model}

\section{Source local partners to create efficient supply chains and distribution channels}

2. Develop robust capabilities to manage regulatory compliance

3. Develop an effective cost management strategy

4. Create a strong due diligence process to identify the right market entry strategies
5. Create a localized manufacturing strategy

6. Invest in workforce development and training

7. Contribute to socioeconomic development

8. Monitor local and global market risks

9. Increase the use of technology to spur growth

10. Set and strictly follow moral and ethical principles

Figure 10: Economic Transformation Model (Source: Source: Ernst \& Young, 2013)

Without running the risk of reporting statistical fiction, a careful evaluation of the macro-level growth and micro-level income evidence must form the basis of any evaluation of Africa's rise. There is a great saying. ${ }^{17}$ that, "a country's greatest asset, by far, is its people, who work, innovate, pay taxes, and, generally, reproduce. How well they do these things depends on their legal, cultural, and natural environments, which can be affected, for good and for ill, by the government."

Leadership is cause, all other is effect.

\section{Endnotes}

\footnotetext{
${ }^{1}$ See http://www.economist.com/printedition/2000-05-13

${ }^{2}$ See http://www.economist.com/node/21541015

${ }^{3}$ See http://www.foreignpolicy.com/articles/2013/01/28/we have no idea if africa is rising

${ }^{4}$ See http://www.afdb.org/fileadmin/uploads/afdb/Documents/Publications/ASJ15\%20Section1\%20Eng.pdf

${ }^{5}$ See http://www.guardian.co.uk/business/2012/nov/20/economics-ghana

${ }^{6}$ See http://www.cornellpress.cornell.edu/book/?gcoi=80140100939320

${ }^{7}$ See http://www.voanews.com/content/world-bank-imf-fault-ethiopias-economic--development-policies123563509/158279.html

${ }^{8}$ See http://www.imf.org/external/pubs/ft/fandd/basics/dutch.htm

${ }^{9}$ See http://www.ispionline.it/sites/default/files/pubblicazioni/sindzingre rev wp48 2013.pdf

${ }^{10}$ See http://users.ox.ac.uk/ econpco/research/pdfs/ManagingCommodityBooms.pdf

${ }^{11}$ See http://siteresources.worldbank.org/INTAFRICA/Resources/Africas-Pulse-brochure Vol6.pdf

${ }^{12}$ See http://www.ey.com/Publication/vwLUAssets/Africa-on-themove/SFILE/Skolkovo Africa on the move Report.pdf

${ }^{13}$ See http://www.africaneconomicoutlook.org/en/in-depth/developing-technical-vocational-skills-inafrica/tvsd-in-specific-contexts/youth-unemployment/

${ }^{14}$ See http://www.census.gov/population/international/files/wp02/wp-02004.pdf

${ }^{15} \mathrm{See}$ http://blogs.ft.com/beyond-brics/2013/03/14/guest-post-africa-stop-catching-up/\#axzz2RbW71epp

${ }^{16}$ See http://www.ifri.org/downloads/notedelifriocpdevajaranetfengler.pdf

${ }^{17}$ See http://www.economist.com/blogs/freeexchange/2013/01/public-accounting
} 


\section{Other Weblinks}

1. http://www.bbc.co.uk/news/business-19745115

2. http://www.africaneconomicoutlook.org/en/in-depth/developing-technical-vocational-skills-in-africa/tvsdin-specific-contexts/youth-unemployment/

3. http://www.africaneconomicoutlook.org/en/

4. http://www.foreignpolicy.com/articles/2013/01/04/the myth of africa s rise?wp login redirect=0

5. http://www.foreignpolicy.com/articles/2013/01/11/sorry but africa s rise is real?wp login redirect=0

6. http://www.economist.com/node/21541008

7. http://business.myjoyonline.com/pages/news/201301/99616.php

8. http://www.imf.org/external/pubs/ft/reo/2012/afr/eng/sreo1012.pdf

9. http://globalpublicsquare.blogs.cnn.com/2013/01/22/get-ready-for-an-africa-boom/

10. http://brandmakernews.com/business-brand/2461/africa-the-next-big-economic-boom.html

11. http://blogs.ft.com/beyond-brics/2013/01/29/nigeria-to-china-we-want-up-the-chain/\#respond

12. http://www.foreignpolicy.com/articles/2013/01/28/we have no idea if africa is rising?wp login redire $\mathrm{ct}=0$

13. http://africanarguments.org/2012/11/20/poor-numbers-how-we-are-misled-by-african-developmentstatistics-and-what-to-do-about-it-\%E2\%80\%93-by-morten-jerven/

14. http://siteresources.worldbank.org/AFRICAEXT/Resources/AFR Growth_Advance Edition.pdf

15. http://www.emergingmarkets.org/Article/2844077/Africa-must-avoid-repeating-commodity-boommistakes.html 